\title{
Causes of Health Care Workers' Exposure to Antineoplastic Drugs: An Exploratory Study
}

\author{
Chun-Yip Hon and Dina Abusitta
}

\begin{abstract}
Background: The exposure of health care workers to antineoplastic drugs is associated with several adverse health effects, including reproductive toxicities and mutagenic effects. Recent studies have confirmed that Canadian health care workers are at risk of exposure to these agents. However, the causes leading to occupational exposure to antineoplastic drugs are unknown.

Objective: To perform an exploratory study to ascertain the immediate and contributing causes of health care workers' exposure to antineoplastic drugs.

Methods: Participants were recruited from 6 acute care facilities in Vancouver, British Columbia. Those agreeing to participate were asked to complete a questionnaire about previous exposure to antineoplastic drugs while at work and to describe the circumstances of each exposure incident. Responses were qualitatively analyzed, and the causes of each incident were classified as immediate (unsafe work acts and/or unsafe working conditions) or contributing (related to the management of the organization, the environment, and/or the physical and mental status of the worker).
\end{abstract}

Results: Completed questionnaires were received from 120 participants, 18 (15.0\%) of whom reported having had previous occupational exposure to antineoplastic drugs. Qualitative analysis of the responses showed 4 categories of immediate causes (needlestick injury, spill, direct contact, and other unintended exposure) and 3 categories of contributing causes (poor communication, inadequate controls, and lack of training). Some incidents had multiple immediate and/or contributing causes.

Conclusions: According to a review of the immediate and contributing causes identified in this study, many of the exposure incidents were deemed preventable. A "hierarchy of controls" should be implemented, including (in the following order) engineering controls, administrative controls, and personal protective equipment. The findings of this study can be used to develop job safety analyses, which can in turn be adopted in guidelines for safe handling of hazardous drugs. Future similar studies are suggested to ensure the generalizability of results.

Keywords: antineoplastic drugs, occupational exposure, causes, exploratory study

Can J Hosp Pharm. 2016;69(3):216-23

\section{RÉSUMÉ}

Contexte : L'exposition des travailleurs de la santé aux antinéoplasiques est associée à plusieurs effets indésirables sur la santé, notamment de la toxicité pour la reproduction et des effets mutagènes. De récentes études ont montré que les travailleurs canadiens de la santé courent le risque d'être exposés à ces agents. Cependant, les causes qui mènent à l'exposition professionnelle aux antinéoplasiques sont inconnues.

Objectif : Réaliser une étude préliminaire dans le but de découvrir les causes immédiates et secondaires entraînant l'exposition des travailleurs de la santé aux antinéoplasiques.

Méthodes : On a recruté des participants auprès de six établissements de soins de courte durée situés à Vancouver en Colombie-Britannique. Ceux qui ont accepté de participer devaient remplir un questionnaire à propos de leurs expositions professionnelles passées aux antinéoplasiques et décrire les circonstances de chacun de ces incidents. Les réponses ont été analysées qualitativement et chaque incident était classé comme de causes : immédiates (gestes dangereux au travail ou conditions de travail dangereuses) ou secondaires (liées à la gestion de l'organisation, de l'environnement ou de l'état physique ou mental du travailleur).

Résultats : Cent vingt participants ont rempli un questionnaire. Parmi eux, 18 (15,0\%) ont signalé avoir déjà subi une exposition professionnelle aux antinéoplasiques. Une analyse qualitative des réponses a montré l'existence de quatre catégories de causes immédiates (piqûre accidentelle avec une aiguille, produit renversé, contact direct et autres expositions non intentionnelles) et de trois catégories de causes secondaires (mauvaise communication, mesures de contrôle inadéquates et manque de formation). Certains incidents avaient plusieurs causes immédiates ou secondaires.

Conclusions : Selon une analyse des différentes causes relevées dans la présente étude, bon nombre des incidents signalés auraient pu être évités. Une « hiérarchisation des contrôles » doit être mise en place. Elle devrait comprendre (dans cet ordre) : des mesures d'ingénierie, des mesures administratives et l'utilisation d'équipement de protection individuelle. Les conclusions de la présente étude peuvent servir à élaborer des analyses de sécurité au travail, qui peuvent à leur tour être intégrées à des lignes directrices pour la manipulation sécuritaire des médicaments dangereux. Il est conseillé de réaliser d'autres études semblables pour s'assurer que les résultats sont généralisables.

Mots clés : antinéoplasiques, exposition professionnelle, causes, étude préliminaire 


\section{INTRODUCTION}

$\mathrm{T}$ he fact that health care workers are at risk of exposure to antineoplastic drugs has been known since the 1970s. ${ }^{1}$ Over the past 4 decades, there have been considerable advances in understanding the health outcomes associated with occupational exposure to antineoplastic drugs, including acute effects, ${ }^{2,3}$ reproductive toxicities, ${ }^{4-6}$ and carcinogenic potential. ${ }^{5,7}$ Recent evidence has confirmed that a range of Canadian health care workers are at risk of exposure. Several studies have found detectable levels of drug contamination on various work surfaces, ${ }^{8-10}$ and others have demonstrated the presence of antineoplastic drugs on health care workers' hands. ${ }^{11,12}$ These findings are noteworthy, given that the main route of exposure to antineoplastic drugs for health care workers is through skin contact. ${ }^{13,14}$ What remains unclear, however, are the causes of occupational exposure. Is it a lack of personal protective equipment, such as gloves, or are more systemic factors involved, such as inadequate training (e.g., not knowing proper safe handling procedures)? To ascertain the causes leading to an incident, it is standard occupational health and safety practice to ask those workers who experienced the incident to reflect on what occurred. Gathering this information is important, because it enables an understanding of the nature and circumstances surrounding the exposure incident. In turn, this understanding allows for the implementation of actions, such as a change in practice or refresher training, to help prevent recurrence.

To the authors' knowledge, no previous studies have explored the causes of health care workers' exposure to antineoplastic drugs. Furthermore, despite the fact that reporting of work-related injuries and illnesses is a legal requirement under the BC Occupational Health and Safety Regulation, ${ }^{15}$ there is an ongoing problem of underreporting with respect to work-related injuries, let alone "near miss" incidents, such as contact with antineoplastic drugs, that do not cause injury. ${ }^{16}$ Therefore, as part of a larger study, we sought to obtain information about causes of exposure from health care workers in British Columbia, by way of an open-ended question on a written questionnaire. We believe that this is a more practical means of gathering details of exposure incidents than reliance on formal reporting. The goal of this exploratory study was to understand the potential mechanisms of health care workers' exposure to antineoplastic drugs and, in turn, to apply this knowledge to the identification of exposure-prevention strategies.

\section{METHODS}

\section{Recruitment of Participants}

Staff from 6 acute care facilities in Vancouver, British Columbia, participated in the study. Potential participants were selected on the basis of site observations suggesting that their job category was at risk of exposure to antineoplastic drugs through direct or indirect contact. ${ }^{17}$ The job categories deemed at risk of exposure to antineoplastic drugs were pharmacist, pharmacy receiver, pharmacy technician, nurse, transport, unit clerk, and others working in the drug administration department (volunteers, oncologists, ward aides, and dietitians). Potential participants were approached by either active recruitment (through a letter of invitation) or passive recruitment (through distribution of consent-to-contact forms at departmental meetings). The participating hospitals' research ethics boards dictated which recruitment method would be used. A member of the research team sent the questionnaire, along with a prepaid return envelope, via regular mail to each consenting participant's preferred mailing address. Questionnaires were disseminated between May 2010 and January 2011. Respondents were given an honorarium (\$25 gift card) after completing the entire questionnaire.

\section{Study Questionnaire}

Details of the self-administered questionnaire have been described elsewhere. ${ }^{18}$ Briefly, the questionnaire was based on existing validated tools, modified for our purposes, and was pretested by representative respondents to ensure the questions would be answered in the intended manner. Ethics approval was obtained from the participating hospitals' research ethics boards before dissemination of the questionnaire. A copy of the full questionnaire is available online (http://antineoexposure.spph. ubc.ca/healthcare-workers-exposure-antineoplastic-drugs/studydocuments).

The sections of the questionnaire pertinent to the current study were demographic data, such as age, sex, and job title; the degree of contact with antineoplastic drugs, such as frequency and duration; and previous exposures (i.e., direct, unintended contact with antineoplastic drugs while at work), with response options of "yes", "no", and "don't know". Any respondent who answered "yes" to the question about previous exposure was then asked to "describe the circumstances [of the incident]" via open-field text.

\section{Data Analysis}

The respondents' characteristics were described according to frequency statistics for each variable, stratified by self-reported previous exposure to antineoplastic drugs (yes, no, or don't know) using Excel software (Microsoft Corporation, Seattle, Washington).

For respondents who indicated a previous exposure incident, their descriptions of the circumstances surrounding the incident were subjected to qualitative analysis to identify themes of causation leading to exposure. ${ }^{19}$ Two broad, prespecified categories based on the root cause theory of accidentsimmediate causes and contributing causes - served as the framework for coding participants' responses. ${ }^{20}$ Immediate causes were 
defined as unsafe work acts and/or unsafe working conditions. Contributing causes, which are less immediate, were factors related to the management of an organization, the environment, and/or the worker's physical and mental status. The initial phase of the qualitative analysis involved reading the incident details and then segmenting the responses via open coding. The second phase involved identifying codes that were similar among multiple respondents and then organizing these into more meaningful themes. Finally, these themes of causation were grouped into 1 of the 2 main categories with respect to the root cause. For each reported incident, more than $1 \mathrm{immediate}$ and/or contributing cause could be assigned. To enhance the reliability of coding, the 2 researchers (C.-Y.H., D.A.) independently coded the incident responses using the aforementioned method. The researchers then met to discuss their respective coding results, and the initial consensus was greater than $90 \%$; subsequently, the outstanding coding differences were discussed until consensus was reached.

\section{RESULTS}

\section{Characteristics of Health Care Workers with Previous Exposure}

It was not possible to calculate a true response rate because of the constraints of the recruitment methods dictated by the various ethics boards; however, the proportions of those contacted who participated in the survey ranged from $55 \%$ to $76 \%$ across the 6 facilities. In total, 174 workers agreed to be contacted, and 120 of these individuals participated in the study. Of the 120 participants who completed a questionnaire, $18(15.0 \%)$ indicated having had exposure to antineoplastic drugs while working, 76 (63.3\%) reported never having been exposed, and $26(21.7 \%)$ were uncertain.

At least 1 exposure incident was reported by participants from each of the 6 sites. Overall, the participants represented 7 job categories, and there was at least 1 report of a previous exposure incident for all but 2 of these categories, the exceptions being transport and others in the drug administration unit (volunteers, oncologists, ward aides, and dietitians). Most of the workers who reported a previous exposure (17/18 [94\%]) were tasked with handling antineoplastic drugs; only one respondent who did not usually handle antineoplastic drugs reported a previous exposure incident. Two-thirds (12/18) of those who reported a previous exposure incident worked with antineoplastic drugs less than $25 \%$ of the time (Table 1 ).

\section{Results of Qualitative Analysis-Causes of Exposure (Themes)}

The 18 participants who indicated that they had a previous exposure provided details of the circumstances surrounding these incidents, which were qualitatively analyzed. Seven themes emerged: needlestick injury, spill, direct skin contact, other unintended exposure, poor communication, inadequate controls, and lack of training. According to the root cause theory of accidents, needlestick injury, spill, direct contact, and unintended exposure were classified as "immediate" causes, and the remaining 3 themes were considered to fall under the purview of an organization's management and therefore were categorized as "contributing" causes. An overview of these themes and their corresponding definitions are presented in Table 2. Further descriptions of each subcategory, with verbatim statements from the respondents, are given below.

\section{Immediate Cause: Needlestick Injury}

Contact through a needlestick injury was reported for 3 incidents, all of which occurred during mixing of the drug:

Have had a few needle pokes while mixing chemotherapy.

The reconstitution needle poked into my thumb after reconstituted a [drug] vial.

\section{Immediate Cause: Spill}

This immediate cause primarily involved IV bags or IV tubing. It was the most prevalent of all immediate causes, with $50 \%(n=9)$ of the reported incidents being related to spills.

Spillage of chemotherapy from IV bag that had been punctured.

Exposed from leaking tubing.

Someone had left a bottle of cytotoxic drug uncapped and it had spilled everywhere.

\section{Immediate Cause: Direct Skin Contact}

As previously mentioned, skin contact is considered the primary route of exposure for health care workers ${ }^{13,14}$; therefore, direct skin contact was classified as an immediate cause. Two incidents were deemed to be the result of direct skin contact:

[Drug] was mixed and applied topically by nurses [Note: It is assumed that there was no glove usage during application.]

We generally have a minimum of one patient each day having chemotherapy and the porter will hand it to me (he is not wearing gloves) in a bag and I will then give it to the nurse by hand with no gloves on either.

\section{Immediate Cause: Other Unintended Exposure}

Six incidents were deemed to be "other unintended exposures". This was essentially a miscellaneous category for incidents not captured by the other immediate causes, including splashes (whereby a liquid is propelled and scattered in the air before contact) and other routes of exposure, such as inhalation.

Pt was being supported to stand while urinating and accidentally voided on my hand while cytotoxic drug was infusing into him.

Spiked a bag with [drug] and poked a hole through the upper part of the stem, a few drops at [sic] the mixture hit my lip and chin.

Prepared chemotherapy drugs in short stay (daycare setting), not prepared in Pharmacy with special hood. 
Table 1. Characteristics of Respondents, Stratified by Previous Occupational Exposure to Antineoplastic Drugs

\begin{tabular}{|c|c|c|c|c|c|c|}
\hline \multirow{3}{*}{$\begin{array}{l}\text { Characteristic } \\
\text { Overall }\end{array}$} & \multicolumn{6}{|c|}{ Previous Exposure Category* } \\
\hline & \multicolumn{2}{|r|}{ Yes } & \multicolumn{2}{|c|}{ Don't know } & \multicolumn{2}{|r|}{ No } \\
\hline & 18 & $(15.0)$ & 26 & $(21.7)$ & 76 & $(63.3)$ \\
\hline \multicolumn{7}{|l|}{ Department } \\
\hline Drug administration & 10 & $(8.3)$ & 16 & $(13.3)$ & 32 & $(26.7)$ \\
\hline Pharmacy & 8 & (6.7) & 8 & $(6.7)$ & 33 & $(27.5)$ \\
\hline Other & 0 & $(0.0)$ & 2 & $(1.7)$ & 11 & $(9.2)$ \\
\hline \multicolumn{7}{|l|}{ Job title } \\
\hline Pharmacist & 1 & $(0.8)$ & 3 & $(2.5)$ & 17 & $(14.2)$ \\
\hline Pharmacy receiver & 1 & $(0.8)$ & 0 & $(0.0)$ & 6 & $(5.0)$ \\
\hline Pharmacy technician & 6 & $(5.0)$ & 6 & $(5.0)$ & 12 & $(10.0)$ \\
\hline Nurse & 9 & (7.5) & 6 & $(5.0)$ & 18 & $(15.0)$ \\
\hline Transport & 0 & $(0.0)$ & 1 & $(0.8)$ & 10 & $(8.3)$ \\
\hline Unit clerk & 1 & $(0.8)$ & 3 & (2.5) & 8 & $(6.7)$ \\
\hline Others in drug administration unit† & 0 & $(0.0)$ & 7 & $(5.8)$ & 5 & $(4.2)$ \\
\hline \multicolumn{7}{|l|}{ Sex } \\
\hline Women & 17 & $(14.2)$ & 22 & $(18.3)$ & 55 & $(45.8)$ \\
\hline Men & 1 & $(0.8)$ & 4 & (3.3) & 21 & $(17.5)$ \\
\hline \multicolumn{7}{|l|}{ Age (years) } \\
\hline $20-29$ & 1 & $(0.8)$ & 3 & $(2.5)$ & 8 & $(6.7)$ \\
\hline $30-39$ & 7 & $(5.8)$ & 4 & (3.3) & 22 & $(18.3)$ \\
\hline $40-49$ & 6 & $(5.0)$ & 12 & $(10.0)$ & 17 & $(14.2)$ \\
\hline $50-59$ & 3 & (2.5) & 3 & $(2.5)$ & 23 & $(19.2)$ \\
\hline$\geq 60$ & 1 & $(0.8)$ & 4 & (3.3) & 6 & $(5.0)$ \\
\hline $\begin{array}{l}\text { Work tenure (months), } \\
\text { mean (range) }\end{array}$ & 127 & $9-378)$ & 114 & 12-321) & 95 & $(0-433)$ \\
\hline \multicolumn{7}{|l|}{$\begin{array}{l}\text { Duty to handle antineoplastic } \\
\text { drugs? }\end{array}$} \\
\hline Yes & 17 & $(14.2)$ & 20 & $(16.7)$ & 57 & $(47.5)$ \\
\hline No & 1 & $(0.8)$ & 6 & $(5.0)$ & 19 & $(15.8)$ \\
\hline \multicolumn{7}{|l|}{$\begin{array}{l}\text { Amount of time handling } \\
\text { antineoplastic drugs }\end{array}$} \\
\hline$<25 \%$ & 12 & $(10.0)$ & 18 & $(15.0)$ & 50 & $(41.7)$ \\
\hline$\geq 25 \%$ & 6 & $(5.0)$ & 8 & $(6.7)$ & 26 & $(21.7)$ \\
\hline
\end{tabular}

\section{Contributing Cause: Poor Communication}

In 2 incidents, there was lack of suitable communication about hazards, in the form of either signage or a warning label, to inform the worker of the presence of antineoplastic drugs. This was considered a contributing cause because one of the duties of a supervisor with respect to occupational health and safety is to warn workers of potential or actual workplace danger.

I picked up loose pills not knowing they were cytotoxic.

Pt on oral chemotherapy and there wasn't any visible info around their area like wall, head of bed.

\section{Contributing Cause: Inadequate Hazard Controls}

Five of the reported incidents involved a lack of control measures that, if present, could have prevented exposure. Occupational health and safety legislation dictates that it is the employer's responsibility to provide such control measures.
Handled receiving [drug] ampules, the glass amps were broken and did not use gloves.

Prepared chemotherapy drugs in short stay (daycare setting), not prepared in Pharmacy with special hood.

\section{Contributing Cause: Lack of Training}

In one instance, a worker reported not receiving any training with respect to hazards and/or proper safe handling precautions. Occupational health and safety legislation clearly outlines that the employer/supervisor is required to provide training to workers regarding hazards in the workplace.

I was never told to wear gloves when handling this medication nor shown any safety measures to take when handling it.

\section{DISCUSSION}

The aim of this study was to explore the various causes, both immediate and contributing, leading to exposure of health care 
This single copy is for your personal, non-commercial use only.

For permission to reprint multiple copies or to order presentation-ready copies for distribution, contact CJHP at cjhpedit@cshp.ca

Table 2. Overview of Categories and Subcategories of Exposure Incidents and Corresponding Definitions

\begin{tabular}{|c|c|c|}
\hline $\begin{array}{l}\text { Main Category } \\
\text { and Subcategory (Theme) }\end{array}$ & $\begin{array}{l}\text { No. of } \\
\text { Incidents* }\end{array}$ & Definition \\
\hline Immediate cause & & Unsafe work acts and/or unsafe working conditions \\
\hline Needlestick injury & 3 & $\begin{array}{l}\text { Exposure from needlestick injury involving a needle } \\
\text { that contained antineoplastic drug }\end{array}$ \\
\hline Spill & 9 & $\begin{array}{l}\text { Incident in which the liquid form of the drug is } \\
\text { allowed to run or fall out of a container by accident }\end{array}$ \\
\hline Direct skin contact & 2 & $\begin{array}{l}\text { Direct contact between worker's skin and the drug } \\
\text { and/or container that held the drug }\end{array}$ \\
\hline Other unintended exposure & 6 & $\begin{array}{l}\text { Accidental/unplanned exposure from splashing of } \\
\text { a drug, fluids from a patient, or inhalation of a drug }\end{array}$ \\
\hline Contributing cause & & $\begin{array}{l}\text { Causes related to the management of an } \\
\text { organization, the environment, and/or the physical } \\
\text { and mental status of the worker }\end{array}$ \\
\hline Poor communication & 2 & $\begin{array}{l}\text { Exposure due to lack of awareness of the presence } \\
\text { of antineoplastic drugs }\end{array}$ \\
\hline Inadequate controls & 5 & $\begin{array}{l}\text { Lack of personal protective equipment (e.g., gloves) } \\
\text { or engineering controls (e.g., biological safety } \\
\text { cabinet) }\end{array}$ \\
\hline Lack of training & 1 & $\begin{array}{l}\text { Lack of training of the worker regarding hazards } \\
\text { and/or safe handling procedures }\end{array}$ \\
\hline
\end{tabular}

workers to antineoplastic drugs, on the basis of self-reported descriptions. Four themes related to immediate causes of an exposure were identified: needlestick injury, spill, direct skin contact, and other unintended exposure. In addition, 3 themes were identified as contributing causes of an incident: poor communication, inadequate controls, and lack of training. These categories of causes were not mutually exclusive: an incident could have multiple immediate causes, as well as several contributing causes. For instance, in the incident involving transfer, without gloves, of a chemotherapy bag from the porter to the survey respondent to a nurse, the immediate cause was direct skin contact with the bag, and the contributing causes were inadequate controls (i.e., no gloves) and, presumably, lack of adequate training (i.e., worker unaware that gloves should be worn when transporting).

Regardless of the cause, the incident descriptions indicate that many of these occupational exposures were likely preventable. In other words, had one or more appropriate control measures been in place, the likelihood of exposure would have been lessened. In general, a "hierarchy of controls" should be considered when attempting to control hazards. This hierarchy, from most to least effective, consists of elimination, substitution (with a less hazardous agent), engineering controls (i.e., modify a design to eliminate the hazard), administrative controls (i.e., change in work practices), and personal protective equipment (e.g., gloves). ${ }^{21}$ Neither elimination nor substitution is considered feasible in the context of chemotherapy-related activities, so they will not be discussed further.

With respect to engineering controls, none of the participating sites were using closed-system transfer devices (CSTDs) at the time of the study. According to the US National Institute of Occupational Health and Safety (NIOSH), ${ }^{1}$ a closed-system device is "a drug transfer device that mechanically prohibits the transfer of environmental contaminants into the system and the escape of hazardous drug or vapour concentrations outside the system”. Several publications have demonstrated the effectiveness of CSTDs in reducing drug contamination on surfaces. ${ }^{22-25}$ In addition, many CSTDs are needle-free and their implementation would therefore reduce the risk of needlestick injuries. ${ }^{26}$ However, the added costs of CSTDs might be a barrier to their adoption. Another engineering control that should be widely implemented is use of a ventilated hood, such as a biological safety cabinet (BSC), when mixing drugs, to prevent possible exposure via inhalation. Although all of the sites participating in this study had BSCs, this type of engineering control is often not available at smaller and/or rural sites where antineoplastic drugs are occasionally prepared (Prescillia Chua, WorkSafeBC, personal communication, January 22, 2016). The requirement that antineoplastic drug preparation be performed in a BSC is consistent with the recommendations of various agencies that have published safe drug handling guidelines, such as NIOSH, the Association paritaire pour la santé et la sécurité du travail du secteur affaires sociales (ASSTSAS), the Canadian Association of Pharmacy in Oncology (CAPhO), and the International Society of Oncology Pharmacy Practitioners (ISOPP). ${ }^{1,27-29}$ The current findings also suggest opportunities for novel engineered solutions. For example, given the prevalence of spills and leaks, engineering controls are recommended in relation to IV bags and tubing. Gloves would also be beneficial in these circumstances, but a more effective solution would be to engineer the devices to prevent leaks and spills in the first place. 
Next in the hierarchy are administrative controls. This category includes training, to ensure that workers are aware of the hazards and have the corresponding means to protect themselves when handling the hazardous material. The results of the survey suggest that training may be inadequate; for example, one respondent reported never having been told to wear gloves or shown any safety measures for handling a hazardous medication. Signs and warnings are another form of administrative control where improvements could be made, as the survey showed that poor communication with respect to hazard notification (i.e., the presence of antineoplastic drugs) led to some exposure incidents.

Personal protective equipment is considered the last line of defence, as it does not eliminate the hazard. Regardless, safe handling guidelines dictate that gloves should be worn whenever contact is possible, including caring for a patient on a chemotherapy regimen, handling a drug spill, handling a damaged or broken drug container, and during transport. ${ }^{27}$ Participants' responses suggested that such equipment was not always used, a finding that is consistent with other studies, which have concluded that health care workers' compliance with gloves and other personal protective equipment is inadequate. ${ }^{18,30,31}$

One limitation of this study was that full identification of all contributing causes was not possible from participants' responses. In most cases, participants would not be aware of the less-visible factors that fall under the purview of an organization's management team, including organization-wide policies and procedures that concern training for safe drug handling and hazard notification (i.e., warning of the presence of antineoplastic drugs), which would have been beneficial to prevent some of the exposure incidents. One proposal to facilitate organizational change with respect to exposure to antineoplastic drugs is to adopt an approach similar to that used to improve health care workers' compliance with universal precautions (to prevent exposure to blood-borne pathogens). ${ }^{32}$ McDiarmid and Condon $^{32}$ found that, through development of a strong safety culture/climate, health care organizations were able to improve compliance with universal precautions. Given the similarities in risk of exposure between blood-borne pathogens and antineoplastic drugs, these authors argued that similar commitment and leadership from health care management are required to reduce the risks associated with occupational exposure to antineoplastic drugs. In addition to improving the safety culture at each hospital where antineoplastic drugs are handled and/or stored, a consistent and concerted effort at the provincial level might also be beneficial in reducing the risk.

Another example where all possible contributing causes could not be identified from the incident descriptions involved exposures that occurred as a result of lack of attention. This is a possible contributing cause for selected incidents (e.g., spillage of an uncapped bottle of cytotoxic drug or needlestick injury). Lack of attention may be the result of shiftwork and/or fatigue-
2 common causes of workplace incidents, especially in the health care sector. ${ }^{33-35}$

The study had some other limitations. Although the overall sample size was adequate, the number of individuals who reported previous exposure was relatively small. Given the recognized underreporting of incidents resulting in actual injuries, we believe that the method employed was appropriate for an exploratory study, and it did yield some novel findings. We obtained details of the exposure incidents through a survey, rather than face-to-face interviews, but interviews might have provided some additional information. We are uncertain when the reported incidents took place, so recall bias is a potential issue and the exposures cannot be related to years worked. However, because of the associated reproductive toxicities, exposure to antineoplastic drugs is a traumatic experience for many health care workers, and we believe that respondents answered to the best of their ability. In addition, the research team recently concluded that there is a lack of compliance with personal protective equipment usage and established best practices, that training for safe drug handling is inconsistent and is not made available to all at-risk job categories, and that there is complacency regarding health care workers' exposure to antineoplastic drugs at the participating sites. ${ }^{18}$ Given these existing issues, we believe that the results of the current study are meaningful, despite lack of knowledge about the timing of incidents. Finally, all of the respondents worked in facilities situated in the Greater Vancouver area, and the results of this study may not be generalizable to other hospitals and/or health authorities.

The findings of this study can be used, in part, to develop or improve upon job safety analyses for those health care job categories that are at potential risk of exposure to antineoplastic drugs. A job safety analysis is a risk assessment tool used to identify and control workplace hazards. ${ }^{36}$ Essentially, it identifies those tasks and/or procedures that can lead to exposure and, in turn, can be used for training and awareness purposes and can be employed to develop procedures to prevent accidents. ${ }^{37}$ Enhanced job safety analyses can subsequently be used to strengthen guidelines for safe handling of hazardous drugs, including (but not limited to) the guidelines produced by NIOSH, ASSTSAS, CAPhO, and ISOPP.

Given the findings of this exploratory study, we believe that a larger study in the future is warranted. For an expanded study, the survey could be disseminated to a larger number of at-risk health care workers, or data could be gathered via face-to-face interviews. Alternatively, a qualitative analysis could be performed on existing exposure incident data, which may contain more underlying contributing causes. With the latter suggestion, however, underreporting of such exposure incidents would still remain a concern. 


\section{CONCLUSION}

This study identified both immediate and contributing causes that could lead to occupational exposure to antineoplastic drugs. However, it was an exploratory study, and additional research is therefore recommended. Regardless of what future studies are undertaken, action to address health care workers' exposure to antineoplastic drugs is critical, because of the increasing number of new cancer cases in Canada ${ }^{38}$ and, in turn, the continued use of antineoplastic drugs, in both hospital and nonhospital settings. Change is possible, because many of the reported exposure incidents are preventable. With knowledge of the immediate and contributing causes of exposure to antineoplastic drugs, we hope that the findings of this study will serve to initiate this call to action and reduce the risk to health care workers.

\section{References}

1. Preventing occupational exposure to antineoplastic and other hazardous drugs in health care settings. Publ. no. 2004-165. Atlanta (GA): Centers for Disease Control and Prevention, National Institute for Occupational Safety and Health; 2004 [cited 2011 Nov 30]. Available from: www.cdc.gov/ niosh/docs/2004-165/

2. McDiarmid M, Egan T. Acute occupational exposure to antineoplastic agents. J Occup Environ Med. 1988;30(12):984-7.

3. Valanis BG, Vollmer WM, Labuhn KT, Glass AG. Association of antineoplastic drug handling with acute adverse effects in pharmacy personnel. Am J Hosp Pharm. 1993;50(3):455-62.

4. Dranitsaris G, Johnston M, Poirier S, Schueller T, Milliken D, Green E, et al. Are health care providers who work with cancer drugs at an increased risk for toxic events? A systematic review and meta-analysis of the literature. J Oncol Pharm Pract. 2005;11(2):69-78.

5. Ratner PA, Spinelli JJ, Beking K, Lorenzi M, Chow Y, Teschke K, et al. Cancer incidence and adverse pregnancy outcome in registered nurses potentially exposed to antineoplastic drugs. BMC Nurs. 2010;9(1):15.

6. Valanis B, Vollmer WM, Steele P. Occupational exposure to antineoplastic agents: self-reported miscarriages and stillbirths among nurses and pharmacists. J Occup Environ Med. 1999;41(8):632-8.

7. Fransman W, Kager H, Meijster T, Heederik D, Kromhout H, Portengen L, et al. Leukemia from dermal exposure to cyclophosphamide among nurses in the Netherlands: quantitative assessment of the risk. Ann Occup Hyg. 2014;58(3):271-82.

8. Hon CY, Teschke K, Chu W, Demers P, Venners S. Antineoplastic drug contamination of surfaces throughout the hospital medication system in Canadian hospitals. J Occup Environ Hyg. 2013;10(7):374-83.

9. Merger D, Tanguay C, Langlois E, Lefebvre M, Bussières JF. Multicenter study of environmental contamination with antineoplastic drugs in 33 Canadian hospitals. Int Arch Occup Environ Health. 2014;87(3):307-13.

10. Berruyer M, Tanguay C, Caron N, Lefebvre M, Bussières JF. Multicenter study of environmental contamination with antineoplastic drugs in 36 Canadian hospitals: a 2013 follow-up study. J Occup Environ Hyg. 2015; 12:87-94

11. Hon CY, Teschke K, Demers PA, Venners S. Antineoplastic drug contamination on the hands of employees working throughout the hospital medication system. Ann Occup Hyg. 2014;58(6):761-70.

12. Hon CY, Astrakianakis G, Danyluk Q, Chu W. Pilot evaluation of dermal contamination by antineoplastic drugs among hospital pharmacy personnel. Can J Hosp Pharm. 2011;64(5):327-32.

13. Fransman W, Vermeulen R, Kromhout H. Occupational dermal exposure to cyclophosphamide in Dutch hospitals: a pilot study. Ann Occup Hyg. 2004; 48(3):237-44.

14. Fransman W, Vermeulen R, Kromhout H. Dermal exposure to cyclophosphamide in hospitals during preparation, nursing and cleaning activities. Int Arch Occup Environ Health. 2005;78(5):403-12.
15. Occupational Health and Safety Regulation. Part 3: Rights and responsibilities. Section 3.19: First aid records. Victoria (BC): WorkSafeBC; 2016 [cited 2016 Feb 2]. Available from: http://www2.worksafebc.com/Publications/ OHSRegulation/Part3.asp\#SectionNumber:3.19

16. Thompson A. The consequences of underreporting workers' compensation claims. CMAJ. 2007;176(3):343-4.

17. Hon CY, Teschke K, Chua P, Venners S, Nakashima L. Occupational exposure to antineoplastic drugs: identification of job categories potentially exposed throughout the hospital medication system. Saf Health Work. 2011;2(3):273-81.

18. Hon CY, Teschke K, Shen H. Healthcare workers' knowledge, perceptions and behaviors regarding antineoplastic drugs: survey from British Columbia, Canada. J Occup Environ Hyg. 2015;12(10):669-77.

19. Boeije H. Analysis in qualitative research. London (UK): Sage Publications; 2010.

20. Raouf A. Accident prevention. In: Encyclopedia of occupational health and safety. Geneva (Switzerland): International Labour Organization; 1998.

21. BS OHSAS 18002:2008 occupational health and safety management systems — guidelines for the implementation of OHSAS 18001:2007. London (UK): BSI Standards; 2008.

22. Siderov J, Kirsa S, McLauchlan R. Reducing workplace cytotoxic surface contamination using a closed-system drug transfer device. J Oncol Pharm Pract. 2010;16(1):19-25.

23. Connor TH, Anderson RW, Sessink PJ, Spivey SM. Effectiveness of a closedsystem device in containing surface contamination with cyclophosphamide and ifosfamide in an i.v. admixture area. Am J Health Pharm. 2002;59(1): 68-72.

24. Yoshida J, Tei G, Mochizuki C, Masu Y, Koda S, Kumagai S. Use of a closed system device to reduce occupational contamination and exposure to antineoplastic drugs in the hospital work environment. Ann Occup Hyg. 2009;53(2):153-60.

25. Sessink PJ, Connor TH, Jorgenson JA, Tyler TG. Reduction in surface contamination with antineoplastic drugs in 22 hospital pharmacies in the US following implementation of a closed-system drug transfer device. J Oncol Pharm Pract. 2011;17(1):39-48.

26. Vyas N, Yiannakis D, Turner A, Sewell GJ. Occupational exposure to anti-cancer drugs: a review of effects of new technology. J Oncol Pharm Pract. 2013;20(4):278-87.

27. Prevention guide: safe handling of hazardous drugs. Montréal (QC): Association paritaire pour la santé et la sécurité du travail du secteur affaires sociales (ASSTSAS); 2008 [cited 2012 Apr 15]. Available from: www.irsst.qc.ca/ media/documents/pubirsst/cg-002.pdf

28. Connor T, McLauchlan R, Vandenbroucke J. ISOPP standards of practice safe handling of cyototoxics. J Oncol Pharm Pract. 2007;13(3 Suppl):1-2.

29. Standards of practice for oncology pharmacy in Canada. Version 2. North Vancouver (BC): Canadian Association of Pharmacy in Oncology; 2009 [cited 2016 Feb 2]. Available from: www.capho.org/sites/default/files/ page-files/StandardsofPracticeFORWEBV2Dprintable.pdf

30. Boiano JM, Steege AL, Sweeney MH. Adherence to safe handling guidelines by healthcare workers who administer antineoplastic drugs. J Occup Environ Hyg. 2014;11(11):728-40.

31. Polovich M, Clark PC. Factors influencing oncology nurses' use of hazardous drug safe-handling precautions. Oncol Nurs Forum. 2012;39(3):E299-309.

32. McDiarmid MA, Condon M. Organizational safety culture/climate and worker compliance with hazardous drug guidelines: lessons from the bloodborne pathogen experience. J Occup Environ Med. 2005;47(7):740-9.

33. Dembe AE, Erickson JB, Delbos RG, Banks SM. The impact of overtime and long work hours on occupational injuries and illnesses: new evidence from the United States. Occup Environ Med. 2005;62(9):588-97.

34. Dembe AE, Erickson JB, Delbos RG, Banks SM. Nonstandard shift schedules and the risk of job-related injuries. Scand J Work Environ Health. 2006;32(3):232-40.

35. Halbesleben JRB. The role of exhaustion and workarounds in predicting occupational injuries: a cross-lagged panel study of health care professionals. J Occup Health Psychol. 2010;15(1):1-16.

36. Job hazard analysis [revised]. OSHA Publ. No. 3071. Washington (DC): US Department of Labour, Occupational Safety and Health Administration; 
This single copy is for your personal, non-commercial use only.

For permission to reprint multiple copies or to order presentation-ready copies for distribution, contact CJHP at cjhpedit@cshp.ca

2002 [cited 2015 July 23] Available from: https://www.osha.gov/ Publications/osha3071.pdf?utm_source=rss\&utm_medium=rss\&utm_ campaign=job-hazard-analysis-13

37. Eidson JV, Reese CD. Chapter 5: Analyzing construction hazards and accidents/incidents. In: Handbook of OSHA construction safety and health. 2nd ed. US Department of Labour, Occupational Safety and Health Administration; 2006. pp. 97-120.

38. Canadian cancer statistics. Toronto (ON): Canadian Cancer Society; 2014 [cited 2014 Aug 25]. Available from: www.cancer.ca/en/cancer-information/ cancer-101/canadian-cancer-statistics-publication/?region=on

Chun-Yip Hon, PhD, CPHI(C), CRSP, CIH, is an Assistant Professor in the School of Occupational and Public Health, Ryerson University, Toronto, Ontario.

Dina Abusitta, BSc, was, at the time of this study, an Occupational Health and Safety student in the School of Occupational and Public Health, Ryerson University, Toronto, Ontario.
Competing interests: None declared.

\section{Address correspondence to:}

Dr Chun-Yip Hon

School of Occupational and Public Health

Ryerson University

350 Victoria Street, POD247C

Toronto ON M5B 2K3

e-mail: cyhon@ryerson.ca

Funding: This work was funded by the WorkSafeBC Research Secretariat (RS2008-OG01).

Acknowledgements: The authors would like to acknowledge Claire Pitcher, Jennifer Shum, and Pearl Siganporia for help in distributing the questionnaires and Dr Lynda Robson of the Institute of Work and Health for presubmission review of this manuscript. The authors also appreciate the time and cooperation of all participating health care workers and their respective organizations.

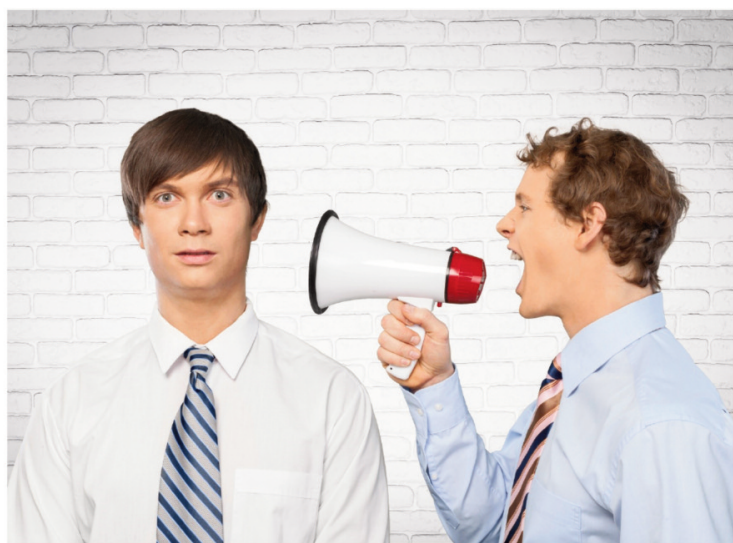

REFER A FRIEND id you know that most of our new members and supporters learn about CSHP through word of mouth?

Over the years, you have referred hundreds of your friends and colleagues to the Society-THANK YOU!

We'd like to encourage you to keep talking about us!

CSHP offers a referral program that allows you to gain credit that can be applied to publications, continuing education programs, and membership.

* Receive a $\mathbf{\$ 1 0}$ credit for referring other members and supporters.

* Receive a $\mathbf{\$ 5}$ credit for referring other students and residents.

New members and supporters will have the opportunity to list you as the person who referred them to CSHP on their application-it's that simple!

For more information, please contact

Membership Services

Telephone: (613) 736-9733, ext. 222

Email: membershipservices@cshp.ca 